\author{
K.K. Pirniyazov*, S.Sh. Rashidova \\ Institute of Polymer Chemistry and Physics, Academy of Sciences of the Republic of Uzbekistan, Tashkent, Uzbekistan \\ (Corresponding author's e-mail: qudrat.pirniyazov@mail.ru)
}

\title{
Study of the kinetics of Bombyx mori chitosan ascorbate formation
}

\begin{abstract}
In this work, for the first time, a water-soluble natural biopolymer of chitosan ascorbate based on Bombyx mori chitosan and ascorbic acid was obtained and kinetic features of the process were determined. Samples of chitosan ascorbate were synthesized, the interaction of chitosan with ascorbic acid was studied by analytical titration. The synthesis was carried out in order to determine the activation energy of formation of the reaction of chitosan ascorbate, in the ratio of chitosan and ascorbic acid (4:1) components for 15 minutes with a reaction temperature ranging from $25^{\circ} \mathrm{C}$ to $65^{\circ} \mathrm{C}$. The results of the kinetic studies show that in the interaction under the study the reaction order on ascorbic acid concentration exceeds the reaction order on chitosan concentration, while the reaction activation energy was determined, which equals to $13.38 \mathrm{~kJ} / \mathrm{mol}$. This result allows us to conclude that during the formation of chitosan ascorbate at $55^{\circ} \mathrm{C}$ the highest equilibrium constant is established, and a further increase in temperature leads to a decrease in the yield and equilibrium constant. The results obtained indicate that with an increase in the concentration of ascorbic acid compared to the one of chitosan, the reaction rate increased almost twice. It was found that with an increase in the reaction time, the average rate of synthesis gradually decreases. This is due to the fact that with an increase in the duration of the reaction in the solution the concentration of unbound (free) ascorbic acid decreases, and as a result, the reaction rate decreases as well.
\end{abstract}

Keywords: chitosan ascorbate, ascorbic acid, donor-acceptor bond, reaction rate, degree of binding.

\section{Introduction}

Ascorbic acid plays an important role in metabolism, acting as both an acceptor and a proton donor in enzymatic systems, due to the mobility of hydrogen atoms in enol hydroxyls at C-3 (pK $\left.K_{a}=4.2\right)$ and C-2 $\left(\mathrm{p} K_{a}=11.6\right)$. Chitosan is biodegradable, nontoxic biopolymer and has properties to stimulate plant growth and inhibit phytopathogenic fungi $[1,2]$. Water-soluble, environmentally safe derivatives of chitosan, in particular, chitosan ascorbate are of great interest in the world. A wide possibility of chitosan (CS) modification allows to obtain its water-soluble derivatives, which exhibits pronounced bioactivity in the growth and development of plants $[2,3]$.

In the literature, there are different views about the mechanisms of interaction of chitosan with ascorbic acid, therefore, the study of the structural and kinetic characteristics of chitosan ascorbate remains relevant. The formation of chitosan ascorbate could be explained based on the interaction of the third (C3-OH) enol hydroxyl group of ascorbic acid and the chitosan amino group with the formation of a donor-acceptor bond [2].

As the authors' [2-6] work shows, donor-acceptor bonds are formed due to the more reactive third $(\mathrm{C} 2-\mathrm{OH}, \mathrm{C} 3-\mathrm{OH})$ enol hydroxyl group of ascorbic acid with the amino group of chitosan. In the reaction of a lone electron pair, the amino groups possess donor properties and confirmed the structure of ascorbate chitosan by using NMR and IR spectroscopy. For obtaining chitosan ascorbate, a potential source of raw materials is chitosan obtained from chitin of Bombyx mori silkworm pupae and widely available ascorbic acid. Scientific research in this aspect is in the initial stage in spite of the fact that there is a great demand for chitosan ascorbate in agriculture. It is known from the scientific literature that the optimal conditions and kinetic features of the reaction of chitosan ascorbate formation are not well understood, therefore, it's synthesizing and the study of the physicochemical and kinetic aspects of the formation of chitosan ascorbate is an urgent task, with special attention being paid to the rational use of natural resources. Chitosan ascorbate was synthesized, kinetic characteristics and energy activation of the process were established on this purpose.

\footnotetext{
${ }^{*}$ Corresponding author
} 


\section{Experimental}

For the purpose of determining $E_{a}$, we used the rheology method in the temperature range $20-50{ }^{\circ} \mathrm{C}$ according to the Arrhenius equation [7]. We have carried out a synthesis, for the first time determined the order of reaction and the activation energy of the reaction of chitosan ascorbate formation. We carried out the reaction of the formation of chitosan ascorbate under the constant conditions with varying concentrations of the initial chitosan to determine the reaction order of the formation of ascorbate chitosan from the concentration of chitosan. The reaction took 30 minutes and the molar concentration differed in the interval of $0.0125-$ $0.1 \mathrm{M}$ of ascorbic acid. The degree of binding of chitosan (CS) to ascorbic acid (AA) was evaluated by the ratio of $\left(\mathrm{M}_{\mathrm{AA}}\right)$ exp./( $\left.\mathrm{M}_{\mathrm{AA}}\right)$ calc. The reaction rate $(\mathrm{v})$ was calculated by the formula,

$$
\mathrm{v}=\frac{\Delta C}{t \times v},
$$

where $\Delta C$ is the change in AA concentration during the complexation reaction; $\mathrm{v}$ is the volume of the reaction mixture.

Ethyl alcohol in a 1:3 ratio to the reaction system was used as a precipitate. The excess amount of ascorbic acid was determined by the alkaline titration method with phenolphthalein indicator or iodometric titration on the basis of the following equation [2]:

$$
\begin{aligned}
\mathrm{C}_{5} \mathrm{H}_{7} \mathrm{O}_{5}-\mathrm{COH}+\mathrm{NaOH} & \rightleftharpoons\left[\mathrm{C}_{5} \mathrm{H}_{7} \mathrm{O}_{5}-\mathrm{CO}-\right] \mathrm{Na}^{+}+\mathrm{HOH} \\
2 \mathrm{C}_{5} \mathrm{H}_{7} \mathrm{O}_{5}-\mathrm{COH}+\mathrm{J}_{2} & \rightleftharpoons 2\left[\mathrm{C}_{5} \mathrm{H}_{7} \mathrm{O}_{5}-\mathrm{C}=\mathrm{O}\right]+2 \mathrm{HJ}
\end{aligned}
$$

The influence of synthesis time and ratio of the initial components on the formation chitosan ascorbate were studied by potentiometric titration.

\section{Results and Discussion}

The results of potentiometric studies were shown that changing molecular weight of initial chitosan slightly effects on formation of chitosan ascorbate. There was detected an increase in the $\mathrm{pH}$ of the medium to 6.3 over 30 minutes during the formation of the reaction of the chitosan ascorbate. Then, the $\mathrm{pH}$ remains constant [8], which could be explained by the maximum interaction of ascorbic acid with chitosan. Therefore, the experiments were carried out during 15-30 minutes. The results are presented in Table 1.

T a b l e 1

Dependence of binding degree of chitosan with ascorbic acid and chitosan ascorbate formation reaction rates from molar concentration of chitosan

\begin{tabular}{|c|c|c|c|}
\hline Concentration of CS, mol/ 1 & $\begin{array}{c}\mathrm{AA}^{*} \text { concentration, } \\
\Delta \mathrm{C} \mathrm{mol} / 1\end{array}$ & Degree of binding, \% & Reaction rate $10^{-5} \mathrm{~mol} / 1 \mathrm{~s}$ \\
\hline 0.2 & 0.0531 & 53.1 & 1.20 \\
\hline 0.3 & 0.0604 & 60.4 & 1.47 \\
\hline 0.4 & 0.0670 & 67.0 & 1.70 \\
\hline 0.5 & 0.0710 & 71.0 & 1.90 \\
\hline
\end{tabular}

${ }^{*}$ AA concentration change

It was clear from the results that there is an increased degree of binding of ascorbic acid and the average reaction rate of ascorbate chitosan formation by increasing molar ratio of initial chitosan compared to ascorbic acid. To estimate the order of the reaction, the dependence of the logarithm of the reaction rate of ascorbate chitosan formation on the concentration of initial chitosan were compiled and the necessary value was determined from the angle.

Figure 1 shows that with an increase in the amount of chitosan, an increase in rate occurs, and the tangent of the angle of inclination is 0.8 , which corresponds to the order of chitosan.

In order to determine the reaction order of the formation of chitosan ascorbate by the amount of ascorbic acid, we synthesized chitosan ascorbate under constant conditions with varying initial acid concentrations. The reaction time is 30 minutes and the molar concentration of chitosan is $0.1 \mathrm{M}$. The results are presented in Table 2 . 
The results of experiments showed that with an increase in the molar ratio of the starting ascorbic acid compared to chitosan, its percentage in the composition of the obtained chitosan ascorbate increases, while with an increase in the ratio of ascorbic acid, the degree of binding decreases.

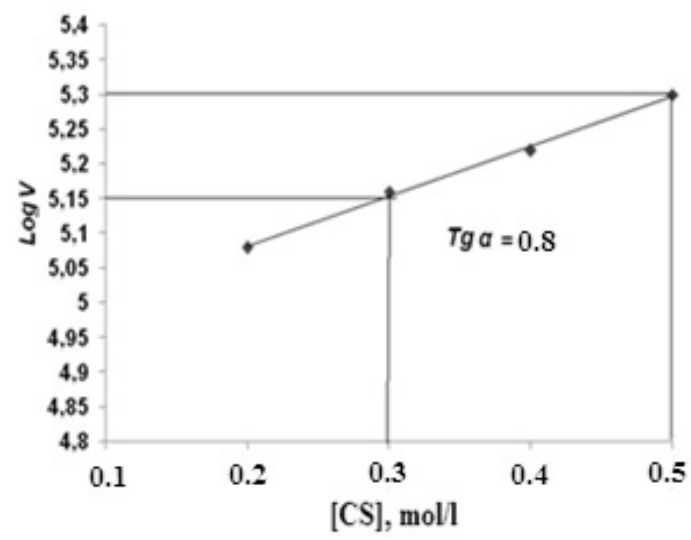

Figure 1. Dependence of the logarithm of the reaction rate of chitosan ascorbate formation on the concentration of the initial chitosan

Table 2

Dependence of the degree of ascorbic acid binding and the rate of chitosan ascorbate formation reaction on the molar concentration of chitosan $\left(t=25^{\circ} \mathrm{C}, \tau=30\right.$ minutes $)$. The molar concentration of chitosan is $0.1 \mathrm{~mol} / \mathrm{l}$

\begin{tabular}{|c|c|c|c|}
\hline Molar concentration AA, mol/1 & $\begin{array}{c}\text { Concentration of AA, } \\
\Delta C \text { mol/l }\end{array}$ & Degree of binding, \% & Reaction rate $\cdot 10^{-5} \mathrm{~mol} / \mathrm{l} \mathrm{s}$ \\
\hline 0.0125 & 0.00875 & 70.0 & 0.49 \\
\hline 0.025 & 0.01835 & 73.4 & 1.10 \\
\hline 0.0375 & 0.03075 & 82.0 & 1.70 \\
\hline 0.0500 & 0.0315 & 63.0 & 1.75 \\
\hline
\end{tabular}

To estimate the order of the reaction, the dependence of the logarithm of reaction rate of ascorbate chitosan formation on the concentration of initial ascorbic acid was compiled and the order of the reaction of ascorbate chitosan formation was determined from the slope.

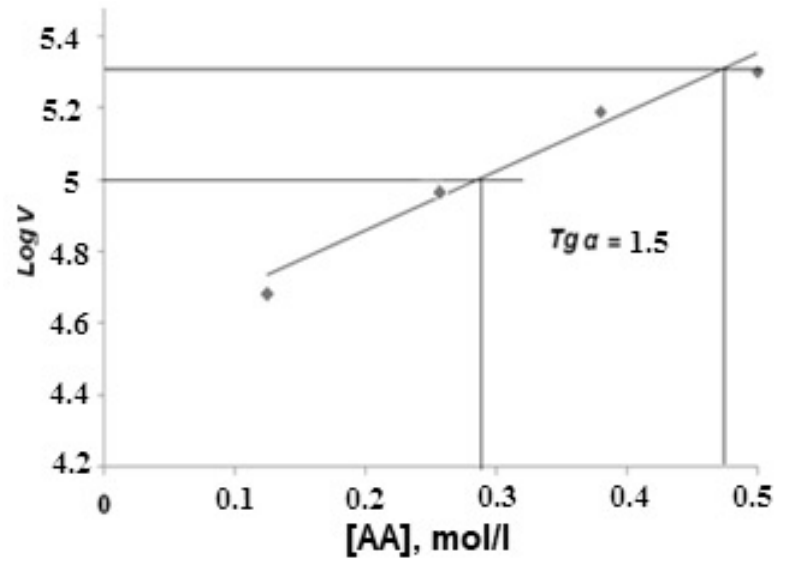

Figure 2. Dependence of the logarithm of the reaction rate of chitosan ascorbate formation on the concentration of the initial ascorbic acid

Figure 2 shows that with an increase in the amount of ascorbic acid, an increase in rate is observed, and the slope is 1.5 , which corresponds to the order of reaction of ascorbic acid. Thus, the reaction rate of the formation of chitosan ascorbate is noticeably higher with an increase in ascorbic acid compared to chitosan. In order to determine the energy, we activated the reaction of ascorbate chitosan formation in the ratio of the 
components CS: AA 4:1 for 15 minutes with the reaction temperature varying from $25^{\circ} \mathrm{C}$ to $65^{\circ} \mathrm{C}$. The concentration of ascorbic acid is $0.033 \mathrm{M}$. The data obtained are presented in Table 3.

Ta b l e 3

Dependence of the degree of ascorbic acid binding and the rate of chitosan ascorbate formation reaction on the reaction temperature. The ratio of the components of $\mathrm{CS}: \mathrm{AA}=0.132: 0.033 \mathrm{~mol} / \mathrm{l}, \tau=15 \mathrm{minutes}$

\begin{tabular}{|c|c|c|c|c|c|c|}
\hline $\mathrm{T},{ }^{\circ} \mathrm{C}$ & $\mathrm{N}, \%$ & $\begin{array}{c}\text { Estimated concentra- } \\
\text { tion AA, } C \%\end{array}$ & $\begin{array}{c}\text { Experimental concen- } \\
\text { tration AA, } C \%\end{array}$ & $\begin{array}{c}\text { Degree of binding, } \\
\%\end{array}$ & $K_{e}$ & $\begin{array}{c}\text { Reaction rate } \\
10^{-5} \mathrm{~mol} / 1 \mathrm{~s}\end{array}$ \\
\hline 25 & 3.95 & 20.0 & 11.2 & 55.0 & 1.04 & 2.01 \\
\hline 35 & 3.77 & 20.0 & 14.0 & 70.0 & 3.20 & 2.56 \\
\hline 45 & 3.74 & 20.0 & 15.1 & 75.5 & 5.08 & 2.77 \\
\hline 55 & 3.71 & 20.0 & 15.4 & 77.0 & 5.80 & 2.83 \\
\hline 65 & 3.75 & 20.0 & 14.6 & 73.3 & 4.20 & 2.72 \\
\hline
\end{tabular}

The results show that with increasing temperature there is an increase in the content (in the range from $11.2 \%$ to $15.4 \%$ ) and in the degree of binding of ascorbic acid. In this case, an increase in the reaction rate from $2.01 \cdot 10^{-5}$ to $2.83 \cdot 10^{-5}$ was found. With an increase of the content of ascorbic acid, a decrease of the fraction of elemental nitrogen was found which confirms the dependence on temperature.

However, after the temperature rises above $55^{\circ} \mathrm{C}$, there is no increase in the content of ascorbic acid, which could be explained by the establishment of a high equilibrium constant under the influence of high temperatures. To calculate the activation energy of the reaction to form a chitosan ascorbate, a graph of the inverse temperature dependence of the reaction rate logarithm was constructed (Fig. 3), and the activation energy is determined from the angle of inclination tangent by the following formula:

$$
\ln \frac{V_{1}}{V_{2}}=\frac{E}{R\left[\frac{1}{T_{1}}-\frac{1}{T_{2}}\right]} ; E_{a}=\frac{2.3 R \log \left(V_{2}-V_{1}\right) T_{1} \times T_{2}}{\Delta T},
$$

where $V_{1}, V_{2}$ are the reaction rate values; $R$ is the universal gas constant; $T_{1}-T_{2}$ is the temperature change.

where $\operatorname{tg} \alpha$ is equal to the sum of equations.

$$
\frac{\log \left(V_{2}-V_{1}\right) T_{1} \times T_{2}}{\Delta T}=\operatorname{tg} \alpha
$$

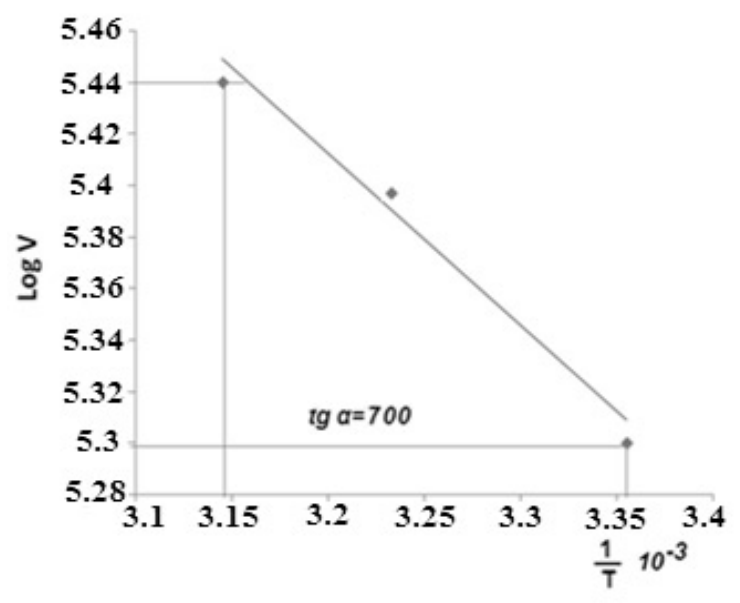

Figure 3. Dependence of the logarithm of the reaction rate of chitosan ascorbate formation on the versus inverse temperature

From the obtained calculations it is clear that the activation energy of the reaction of ascorbate chitosan formation is $13.38 \mathrm{~kJ} / \mathrm{mol}$. This suggests that with increasing temperature, the reaction rate increases gradually and affects the value of activation energy. This result allows us to conclude that during the formation of chitosan ascorbate at $55^{\circ} \mathrm{C}$, the highest equilibrium constant is established and a further increase in temperature leads to a decrease in the yield and reaction formation constant. 


\title{
Conclusions
}

The reaction orders for the formation of chitosan ascorbate by chitosan and ascorbic acid were determined and were equal to $0.8-1.5$, respectively, which indicates that with an increase in the concentration of ascorbic acid compared to chitosan, the reaction rate almost doubled. The effect of temperature on the chitosan ascorbate formation reaction were determined and the results confirmed that temperature $55{ }^{\circ} \mathrm{C}$ was the optimal condition. Decreases in equilibrium constant and ascorbic acid binding degree were found at temperatures above $55^{\circ} \mathrm{C}$. The activation energy value of the reaction confirmed the interaction of chitosan with ascorbic acid to form a donor-acceptor bond.

\section{References}

1 Ваел Ш.М. Наночастицы хитозана как носители биологически активных веществ: автореф. дис. ... канд. хим. наук: спец. 02.00.06 - «Высокомолекулярные соединения» / Ш.M. Ваел. - М., 2012. — 23 c. — URL: http://www.dissercat.com.

2 Pirniyazov K.K. Synthesis and structural characteristics of the ascorbate chitosan Bombyx mori / K.K. Pirniyazov, S.Sh. Rashidova // American journal of research. — 2019. — № 7-8. — P. 114-119. DOI: http://dx.doi.org/10.26739/2573-56162019-8-10.

3 Hafsa J.B. Synthesis, characterization, antioxidant and antibacterial proprieties of chitosan ascorbate / J.B. Hafsa, M.A. Charfeddine, K.L. Smach, et al. // International journal of pharmaceutical, chemical and biological sciences. — 2014. № 4 (4). - P. 1072-1081. — URL: www.ijpcbs.com.

4 Tian X.L. Synthesis and evaluation of chitosan-vitamin C complex / X.L. Tian, D.F. Tian, et al. // Indian J. Pharm Sci. 2009. — Vol. 71(4). — P. 371-376. DOI: 10.4103/0250-474X.57284.

5 Карапетян Г.Э. Использование аскорбата хитозана в мембранном дренировании гнойных ран: автореф. дис. ... канд. мед. наук: спец. 14.00.27 - «Хирургия» / Г.Э. Карапетян. - Красноярск, 2005. - 27 c. — URL: http://www.dissercat.com.

6 Малинкина О.Н. Оценка химического взаимодействия гидрохлорида хитозана с аскорбиновой кислотой методами ИК- и ЯМР-спектроскопии / О.Н. Малинкина, А.А. Провозина, А.Б. Шиповская // Изв. Саратов. ун-та. Сер. Химия. Биология. Экология. — 2014. - Т. 14, № 3. - С. 20-24.

7 Ying-Chien Ch. Preparation and characterization of water-soluble chitosan produced by by Maillard reaction / Ch.YingChien, F.T. Cheng, F.L. Chin // Fisheries Science. - 2006. — Vol. 72. - P. 1096-1103. DOI: 101111/J.1444-2906.2006.01261.x.

8 Пирниязов К.К. Потенциометрические исследования аскорбата хитозана Bombyx mori / К.К. Пирниязов, С.Ш. Рашидова // VII Всерос. Каргинская конф.: сб. тез. - М., 2017. — С. 332. — URL: http://www.kargin.msu.ru.

\author{
К.К. Пирниязов, С.Ш. Рашидова
}

\section{Bombyx mori аскорбат хитозанының пайда болу кинетикасын зерттеу}

\begin{abstract}
Мақала алғаш рет Bombyx mori хитозаны (Х3) және аскорбин қышқылының (АҚ) негізінде суда еритін табиғи биополимер аскорбат хитозаны (АХ3) алынған және кинетикалық ерекшеліктері анықталған. Хитозан аскорбатының үлгілері синтезделді, хитозанның аскорбин қышқылымен аналитикалық титрлеу арқылы әрекеттесуі зерттелді. Хитозан аскорбатының түзілу реакциясының активтендіру энергиясын анықтау үшін біз компоненттердің арақатынасы Х3:АК 4:1 болғанда, 15 минут аралығымен реакция температурасы $25^{\circ} \mathrm{C}$-тен $65^{\circ} \mathrm{C}$-ке дейін бақыланды. Кинетикалық зерттеулердің нәтижелері зерттелген өзара әрекеттесуде аскорбин қышқылының концентрациясы бойынша реакция тәртібі хитозанның концентрациясындағы реакция тәртібінен асып кететінін, реакцияның активтену энергиясы бір уақытта анықталатындығын және 13,38 кДж/мольге тең болатындығын көрсетті. Нәтижелер тепе-теңдіктің ең жоғары тұрақты мәні $55^{\circ} \mathrm{C}$-те аскорбатты хитозан түзілгенде, температураның артуымен реакция тұрақты және төмендеуіне әкелетіндігін растады. Реакцияның орташа жылдамдығы реакция ұзақтығының артуымен төмендегені анықталды. Бұл реакция ұзақтығының ұлғаюына байланысты ерітіндідегі бос аскорбин қышқылының концентрациясының төмендеуіне байланысты реакция жылдамдығының төмендеуін сипаттайды.
\end{abstract}

Кілm сөздер: хитозан аскорбаты, аскорбин қышқылы, донор-акцепторлық байланыс, реакция жылдамдығы, байланысу дәрежесі.

\section{К.К. Пирниязов, С.Ш. Рашидова}

\section{Изучение кинетики образования аскорбата хитозана Bombyx mori}

В статье впервые был получен водорастворимый природный биополимер - аскорбат хитозана (АХЗ) на основе хитозана (Х3) Bombyx mori и аскорбиновой кислоты (АК) и определены кинетические осо- 
бенности. Синтезированы образцы аскорбата хитозана, изучено взаимодействие хитозана с аскорбиновой кислотой аналитическим титрованием. С целью определения энергии активации реакции образования аскорбата хитозана проводили синтез в соотношении компонентов ХЗ:АК 4:1 в течение 15 мин с варьированием температуры реакции от 25 до $65^{\circ} \mathrm{C}$. Результаты проведенных кинетических исследований показывают, что в изучаемом взаимодействии порядок реакции по концентрации аскорбиновой кислоты превышает порядок реакции по концентрации хитозана, одновременно определена энергия активация реакции, которая равняется 13,38 кДж/моль. Данный результат позволяет сделать вывод о том, что в процессе образования аскорбата хитозана при $55^{\circ} \mathrm{C}$ устанавливается самая высокая константа равновесия, а дальнейшее увеличение температуры приводит к уменьшению выхода и константы равновесия. Полученные результаты свидетельствуют о том, что с увеличением концентрации аскорбиновой кислоты по сравнению с хитозаном скорость реакции повысилась практически в два раза. Установлено, что с увеличением времени реакции постепенно уменьшается средняя скорость синтеза. Это связано с тем, что с повышением продолжительности реакции в растворе уменьшается концентрация несвязанной (свободной) аскорбиновой кислоты, вследствие этого происходит снижение скорости реакции.

Ключевые слова: аскорбат хитозана, аскорбиновая кислота, донорно-акцепторная связь, скорость реакции, степень связывания.

\section{References}

1 Waiel, Sh.M. (2012). Nanochastitsy khitozana kak nositeli biolohicheski aktivnykh veshchestv [Chitosan nanoparticles as carriers of biologically active substances]. Extended abstract of candidate's thesis. Moscow. Retrieved from http://www.dissercat.com [in Russian].

2 Pirniyazov, K.K., \& Rashidova, S.Sh. (2019). Synthesis and structural characteristics of the ascorbate chitosan Bombyx mori. American journal of research, 7-8, 114-119. DOI: http://dx.doi.org/10.26739/2573-5616-2019-8-10.

3 Hafsa, J.B., Charfeddine, M.A., \& Smach, K.L. et al. (2014). Synthesis, characterization, antioxidant and antibacterial proprieties of chitosan ascorbate. International journal of pharmaceutical, chemical and biological sciences, 4(4), 1072-1081. Retrieved from www.ijpcbs.com.

4 Tian, X.L., \& Tian, D.F., et al. (2009). Synthesis and evaluation of chitosan-vitamin C complex. Indian J. Pharm Sci., 71, 4, 371-376. Retrieved from DOI: 10.4103/0250-474X.57284.

5 Karapetian, H.E. (2005). Ispolzovanie askorbata khitozana $v$ membrannom drenirovanii hnoinykh ran [Use of chitosan ascorbate in membrane drainage of purulent wounds]. Extended abstract of candidate's thesis. Krasnoyarsk. Retrieved from $\mathrm{http}: / /$ www.dissercat.com [in Russian].

6 Malinkina, O.N., Provozina, A.A., \& Shipovskaia, A.B. (2014). Otsenka khimicheskoho vzaimodeistviia hidrokhlorida khitozana s askorbinovoi kislotoi metodami IK- i YaMR-spektroskopii [Assessment of the chemical interaction of chitosan hydrochloride with ascorbic acid by IR and NMR spectroscopy]. Izvestiia Saratovskoho universiteta. Seriia Khimiia. Biolohiia. Ekolohiia - News of the Saratov University. Ser. Chemistry. Biology. Ecology, 14, 3, 20-24 [in Russian].

7 Ying-Chien, Ch., Cheng, F.T., \& Chin, F.L. (2006). Preparation and characterization of water-soluble chitosan produced by by Maillard reaction. Fisheries Science, 72, 1096-1103. DOI: 101111/J.1444-2906.2006.01261.x.

8 Pirniiazov, K.K., Rashidova, S.Sh. (2017). Potentsiometricheskie issledovaniia askorbata khitozana Bombyx mori [Potentiometric study of chitosan ascorbate Bombyx mori]. VII Vserossiiskaia Karhinskaia konferentsiia - VII All-Russian Karginsky Conference of Polymers. (p. 332). Retrieved from http://www.kargin.msu.ru [in Russian]. 